\title{
Grape (Vitis Vinifera) Pomace Flour as Pigment Agent of Quail Eggs
}

http://dx.doi.org/10.1590/1806-9061-2017-0561

Technical Note

\section{-Author(s)}

\section{Fróes HG}

Jácome IMTD

Tavares RA

Garcia RG"

Domingues CHF"

Bevilaqua TMS"

Martinelli M'

Naas IA"

Borille R"

Animal Science Department, Federal University of Santa Maria, UFSM/CESNORS, Palmeira das Missões, RS, Brasil

" College of Agrarian Sciences, FCA/UFGD, Dourados, MS, Brasil

III College of Administration and Economic Science, FACE/UFGD, Dourados, MS, Brasil

\section{Mail Address}

Corresponding author e-mail address Carla Heloisa de Faria Domingues

Rua Cláudio Goelzer n 1500, Residencial Itamaracá, Bairro Parque Alvorada, CEP: 79823-352, Dourados, MS, Brasil. Tel: (67) 3410-2063

Email: carlafariadomingues@hotmail.com

\section{EKeywords}

additives, egg production, egg quality Haugh Unit, natural pigment.

\section{ABSTRACT}

The aim of the study was to evaluate the effect of dietary grape pomace flour (GPF) inclusion on the performance and egg quality of European quails (Coturnix coturnix coturnix) in lay. One hundred ninety-two (192), 42-day-old quails were distributed in a completely randomized design with four treatments $(0,2,4$ and $6 \%$ grape pomace flour inclusion) with six replicates of eight birds each. The performance parameters egg weight (g), average feed intake ( $\mathrm{g} / \mathrm{bird})$, total feed intake (g/bird), egg production (\%) and feed conversion ratio ( $\mathrm{kg} / \mathrm{dozen})$ were evaluated, as well as egg quality traits Haugh unit, albumen weight $(\mathrm{g})$, yolk weight $(\mathrm{g})$, eggshell thickness $(\mathrm{mm})$, egg specific gravity $\left(\mathrm{g} / \mathrm{cm}^{3}\right)$, and yolk pigmentation. There was no effect $(p>0.05)$ of dietary GPF levels on egg production, feed intake, or feed conversion ratio. Egg weight, albumen weight, and egg specific gravity linearly decreased $(p<0.05)$ as GPM levels increased in the diet. Haugh unit and eggshell thickness were not affected ( $p>0.05)$ by the treatments. A quadratic effect $(p<0.05)$ was observed for yolk weight, with an estimated maximal inclusion level of grape pomace flour of $4.18 \%$ to obtain the highest yolk weight. A quadratic effect $(p<0.05)$ was also observed on yolk pigmentation, with an estimated minimal level of 3.2\% for this parameter. The minimal inclusion of $3.2 \%$ of grape pomace flour in quail diets influenced the egg yolk pigmentation, demonstrating its efficiency as a pigmentation additive.

\section{INTRODUCTION}

New management technologies adopted by the industry have allowed the growth of Brazilian quail production. There have also been advancements in the commercialization of quail products, such as eggs and meat, supported by improved genetic strains. Increased activity has been observed in academic studies in the areas of breeding, nutrition, and husbandry (Keener et al., 2000; Ipek et al., 2003). Egg production remains the primary purpose of quail rearing. In 2015, Brazilian quail egg production reached nearly 340 million dozen, showing an increase of $20.2 \%$ over 2014 (IBGE, 2015), evidencing the economic importance of this product.

Consumers associate yolk color with egg quality and adequate nutrition, and prefer yellow-orange yolks (Hernández et al., 2001). Pigments and colorants are sometimes added to poultry feeds to enhance yolk color. These additives may be of natural or synthetic origin. In poultry, canthaxanthin, a synthetic red carotenoid pigment, is predominantly used. However, there is a worldwide consumer trend of preferring natural pigment sources and rejecting synthetic ones. 
Fróes HG, Jácome IMTD, Tavares RA,

Garcia RG, Domingues CHF,

Bevilaqua TMS, Martinelli M

Naas IA, Borille R
Grape (Vitis Vinifera) Pomace Flour as Pigment Agent of Quail Eggs
Natural pigments have already been applied in poultry production, and demonstrated satisfactory results. Zahrrojian et al. (2013) studied the effects of the dietary addition of marine algae (Spirulina platensis) at $0,1.5,2.0$ and $2.5 \%$ on egg quality and production performance of laying chickens and observed a significant increase in egg yolk color when hens were fed with Spirulina. The authors suggest the addition of 2.0-2.5\% Spirulina to the diet to produce an aesthetically pleasing yolk color. Mirzah \& Djulardi (2017) conducted an experiment to determine the effect of marigold (Tagetes erecta) flower extract (MFE) as a feed additive on performance and egg quality of laying Japanese quails (Coturnix coturnix japonica). The authors concluded that 15 ppm MFE in the diet improved the performance, improved egg quality, reduced egg cholesterol levels and increased egg yolk color of quail eggs.

No studies using grape pomace flour as a feed additive for quails were found in literature. The grape is a natural pigment and may be possibly be used an alternative to synthetic additives. Grape pomace is the residue left from fruit processing and contains the skins, seeds, and pulp that remains after crushing grapes for wine and juice production (Bagchi et al., 2000; Shrikhande, 2000; Llobera \& Canellas, 2007). This by-product contains large quantities of phenolic compounds - around $20-30 \%$ in the skin and 60-70\% in the seeds - which include anthocyanins, which are pigments that give the purple color to grapes and their products (Monrad et al., 2010).

The aim of the present study was to evaluate the effects of using grape pomace flour on performance and egg quality of quails.

\section{MATERIAL AND METHODS}

The experiment was conducted in the Poultry Section of the Department of Animal Science and Biological Sciences, Universidade Federal de Santa Maria, Palmeira das Missões, RS, Brazil, located at $634 \mathrm{~m}$ altitude, $27^{\circ} 53^{\prime} 58^{\prime \prime} \mathrm{S}$ latitude, and $53^{\circ} 26^{\prime}$ $45^{\prime \prime} \mathrm{W}$ longitude. The experimental protocol was approved by the Animal Ethics Committee (CEUA) of the Universidade Federal de Santa Maria (UFSM), Palmeira das Missões, Brazil, under protocol number 015/2015.

A total of 192 European quails (Coturnix coturnix coturnix), with $\pm 180 \mathrm{~g}$ initial weight and 42 days initial age, were used in the experiment. The quails were housed in cages (eight birds per cage), measuring
$0.50 \mathrm{~m} \times 0.50 \mathrm{~m} \times 0.15 \mathrm{~m}$ and equipped with automatic drinkers and feeders, in an environmentally-controlled room. Water was available ad libitum, and the feed was provided twice daily at an allowance $30 \mathrm{~g} / \mathrm{bird} /$ day during the experimental period. A continuous lighting program of 16 hours of light daily was applied using artificial lighting. The quails were distributed in a completely randomized design with four treatments with six replicates (cages) of eight birds each, totaling 24 cages. The experiment lasted 84 days and was divided into three periods of 28 days each.

The experimental diets (Table 1) were based on corn and soybean meal and formulated according to the recommendations of Rostagno et al. (2011). The variable portion consisted grape pomace flour added at the expense of kaolin, according to treatment. The experimental treatments consisted of a basal diet and basal diets with the addition of $2 \%, 4 \%$, or $6 \%$ grape pomace flour.

The pomace from a Vitis vinifera grape variety was obtained from wine industry of Santa Maria, state of Rio Grande do Sul. The pomace was weighed and spread in a thin layer on perforated trays. The pomace was then placed in a greenhouse with air circulation at $70^{\circ} \mathrm{C}$ for $2 \mathrm{~h}$ for drying. After drying, the pomace was ground in an analytical mill (Table 2). The grape pomace flour chemically analyzed for moisture, ash, crude protein, ether extract, and crude fiber contents according to the methods of the AOAC (2007). Moisture content was determined by drying the samples in an oven at $105^{\circ} \mathrm{C} \pm 5^{\circ} \mathrm{C}$ until constant weight. Ash content was obtained by burning the samples in a muffle at 550 ${ }^{\circ} \mathrm{C}$ until a constant weight. Crude protein content was determined by the Kjeldahl method, and the obtained nitrogen content was multiplied by a factor 6.25 to convert the result into crude protein. Ether extract content were obtained by the Soxhlet extraction method. Crude fiber content was determined by the enzymatic-gravimetric method.

Performance and egg quality were evaluated for each 28-d period. Performance parameters included egg weight (g), average daily feed intake (g/bird), total feed intake (g/bird), egg production (\%), and feed conversion ratio ( $\mathrm{kg}$ feed/dozen eggs). On the last day of each 28-day period, four eggs replicate were collected to determine the following egg quality traits: albumen weight (g), yolk weight (g), eggshell thickness $(\mathrm{mm})$, egg specific gravity $\left(\mathrm{g} / \mathrm{cm}^{3}\right)$, yolk pigmentation, and Haugh units, as $100 \log (h+7.57-1.7$ W 0.37), where: $\mathrm{h}=$ albumen height in $\mathrm{mm}$ and $\mathrm{W}=$ egg weight in $\mathrm{g}$. 
Fróes HG, Jácome IMTD, Tavares RA,

Garcia RG, Domingues CHF,

Bevilaqua TMS, Martinelli M,

Naas IA, Borille R

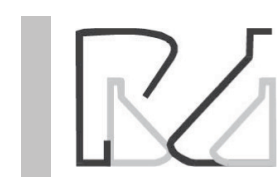

Grape (Vitis Vinifera) Pomace Flour as Pigment Agent of Quail Eggs

Table 1 - Ingredients and calculated nutritional composition of the experimental diets.

\begin{tabular}{|c|c|c|c|c|}
\hline \multirow{2}{*}{ Ingredients } & \multicolumn{4}{|c|}{ Grape pomace flour levels (\%) } \\
\hline & 0 & 2 & 4 & 6 \\
\hline Corn & 48.60 & 48.60 & 48.60 & 48.60 \\
\hline${ }^{\star}$ Commercial concentrate for laying quails ( $\left.41 \% C P\right)$ & 39.89 & 39.89 & 39.89 & 39.89 \\
\hline Dicalcium phosphate & 1.72 & 1.72 & 1.72 & 1.72 \\
\hline Limestone & 3.44 & 3.62 & 3.79 & 3.79 \\
\hline Salt & 0.35 & 0.18 & - & - \\
\hline Kaolin & 6.00 & 4.00 & 2.00 & - \\
\hline Grape pomace flour & - & 2.00 & 4.00 & 6.00 \\
\hline TOTAL & 100 & 100 & 100 & 100 \\
\hline \multicolumn{5}{|l|}{ Nutritional composition } \\
\hline Metabolizable energy (kcal/kg) & 2800 & 2800 & 2800 & 2800 \\
\hline Crude protein (\%) & 20.19 & 20.28 & 20.37 & 20.46 \\
\hline Digestible lysine (\%) & 0.97 & 0.97 & 0.97 & 0.97 \\
\hline Digestible methionine (\%) & 0.47 & 0.47 & 0.47 & 0.47 \\
\hline Calcium (\%) & 3.17 & 3.23 & 3.30 & 3.30 \\
\hline Total phosphorus (P) (\%) & 1.06 & 1.06 & 1.07 & 1.07 \\
\hline Available P (\%) & 0.97 & 0.97 & 0.97 & 0.97 \\
\hline Digestible P (\%) & 0.27 & 0.27 & 0.27 & 0.27 \\
\hline Potassium (\%) & 0.14 & 0.14 & 0.14 & 0.14 \\
\hline Sodium (\%) & 0.15 & 0.15 & 0.15 & 0.22 \\
\hline Chloride (\%) & 0.24 & 0.13 & 0.03 & 0.03 \\
\hline Crude Fiber (\%) & 4.83 & 5.21 & 5.59 & 5.97 \\
\hline Ether extract (\%) & 2.57 & 2.61 & 2.65 & 2.69 \\
\hline Ash (\%) & 14.85 & 14.88 & 14.91 & 14.94 \\
\hline
\end{tabular}

${ }^{*}$ Commercial Concentrate for laying quails (CP 41\%), with mineral and vitamin premix. Guaranteed levels = Mg: 0.01 \%; Mn: 108 mg/kg; Zn: 57.6 mg/kg; Fe: 72 mg/kg; Cu: 14.4 mg/kg; l: 1.0 mg/kg; Se: 0.4 mg/kg; A vit.: 14400 Ul/kg; D3 vit.: 2880 UI/kg; E vit.: 36 Ul/kg; K3 vit.: 2.32 mg/kg; B1 vit.: 2.32 mg/kg; B2 vit.: 7.2 mg/kg; Pantothenic acid: 14.4 mg/ kg; B6 vit.: 4.32; B12 vit.: $23.04 \mathrm{mcg} / \mathrm{kg}$; Folic acid: $0.72 \mathrm{mg} / \mathrm{kg}$; Choline: $160 \mathrm{mg} / \mathrm{kg}$.

Table 2 - Chemical composition of the grape pomace flour included in the experimental diets.

\begin{tabular}{lc}
\hline & $\% / \mathrm{kg}$ \\
\hline Humidity & 8 \\
Ash & 4.7 \\
Crude Protein & 4.5 \\
Ether extract & 2 \\
Crude fiber & 19 \\
\hline
\end{tabular}

Feed residues were weighed during the last three days of each cycle, and total feed intake was calculated as the difference between total feed offer and feed residues. Feed conversion ratio in $\mathrm{kg} / \mathrm{dozen}$ eggs was calculated as total feed intake $(\mathrm{kg})$ divided by the dozens of eggs produced in each experimental unit. Egg production, eggs were collected daily for 17 hours per 28-d period, and at the end of each period the total production was counted, and the percentage relative to the total period production of total eggs produced was calculated.

Egg specific gravity was determined by immersing eggs in graded $\mathrm{NaCl}$ solutions with densities ranging between 1.065 and $1.100 \mathrm{~g} / \mathrm{cm}^{3}$ at0.005 gradients, according to the methodology of Moreng and Avens (1990). Yolk pigmentation was evaluated using the colorimetric scale of the DSM yolk color fan (DSM®) Nutritional Products,) of 1 to 15 points corresponding increasing pigmentation of egg yolks.

Data were analyzed by analysis of variance at 95\% confidence level, and submitted to polynomial regressions against GPF levels, using the statistical software Minitab 16.1 (2010).

\section{RESULTS AND DISCUSSION}

There was no effect ( $p>0.05$ ) of grape pomace flour levels on egg production, feed intake (both average and total), or feed conversion ratio. According to Leeson \& Summers (2001), voluntary feed intake is directly related to the palatability of the feed. In this study, feed intake was not affected ( $p>0.05)$, indicating that the addition of grape pomace flour to the diet did not change the palatability of the experimental diets. These results are in agreement with those of Rossi et al. (2015), who reported that the addition of increasing sweet pepper levels $(0,75$, 125 , and $225 \mathrm{ppm}$ ) to laying chicken diets did not affect egg production, feed intake, egg mass, or feed conversion ratio. 
Fróes HG, Jácome IMTD, Tavares RA,

Garcia RG, Domingues CHF,

Bevilaqua TMS, Martinelli M,

Naas IA, Borille R Grape (Vitis Vinifera) Pomace Flour as Pigment Agent
of Quail Eggs
Several studies report the lack of influence of natural sources of antioxidants on the feed intake (Radwan et al., 2008; Zhao et al., 2011; Özeku et al., 2011; Bozkurt et al., 2012) and laying performance (Özeku et al., 2011; Bozkurt et al., 2012). However, Radwan et al. (2008) found that although feed intake was not affected, the dietary inclusion of $1 \%$ of oregano, rosemary or thyme, or $0.5 \%$ turmeric promoted better productive performance in laying hens.

Egg weight linearly decreased with increasing dietary GPF levels (Figure 1). A possible explanation for this result is that grape pomace is particularly rich in a wide range of polyphenols. One these polyphenols formerly known as tannins are considered antinutritional and has adverse effects on animal nutrition, as discussed below. According to Brenes (2016), the main limitations of the inclusion of grape pomace in monogastric feeds are its high levels of lignified cell wall fraction and tannins. On the other hand, Salici et al. (2011), in a study evaluating the inclusion of grape seed flour $(0.5,1.0$, and $1.5 \%)$ in Japanese quail diets, did not observe any effect on egg weight, possibly due to the low levels of grape seed flour evaluated.

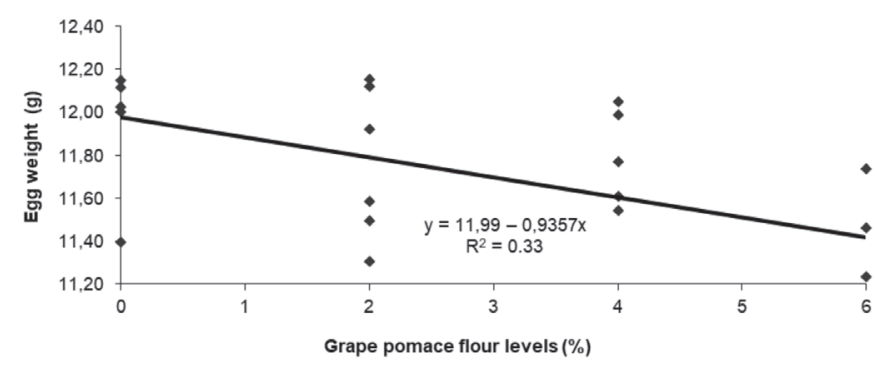

Figure 1 - Egg weight of quails fed diets containing different levels of grape pomace flour during lay.

As to egg quality traits, there was no effect ( $p>0.05)$ of treatments on Haugh units or eggshell thickness. However, there was a decreasing linear effect on albumen weight and specific gravity (Figure 2) as GPF inclusion levels increased. Grape pomace flour has high fiber content, and non-ruminant animals (with the exception of horses and rabbits) have limited utilization of dietary fiber as their large intestine do not present an active cellulolytic microbiota, and, therefore, high dietary fiber content may reduce the digestibility of ingredients (Betercchini, 2012). It has been shown that the inclusion of polyphenolic grape extracts in poultry diets may reduce the digestibility of fat (Brenes et al., 2008), protein, and some amino acids, such as proline and cystine (Chamorro et al., 2013). Tannins may potentially precipitate proteins, thereby reducing protein and amino acid digestibility. The binding of tannins to both dietary and endogenous proteins (such as digestive enzymes and proteins located at the luminal side of the intestinal tract) has been used to explain the reduced protein and amino acid digestibility in tannin-containing diets (Gilani et al., 2012).
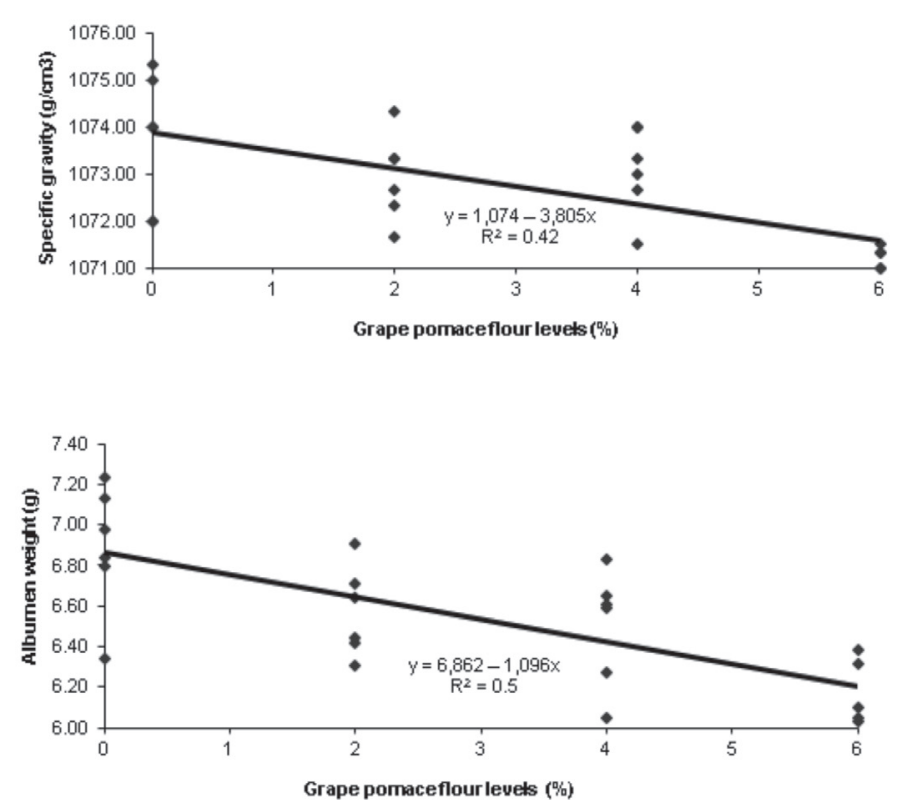

Figure 2 - Albumen weight $(\mathrm{g})$ and egg specific gravity $(\mathrm{g} / \mathrm{cm} 3)$ of quails fed diets containing different levels of grape pomace flour during lay.

Kara et al. (2016) included $4 \%$ and $6 \%$ grape pomace in laying hen diets, but did not observe any significant effects on egg quality. On the other hand, Ozgan (2008), reported an increase in albumen height and albumen index with the addition of $2 \%$ grape pomace to laying hen diets.

A quadratic effect of GPF inclusion on yolk weight was observed, with the highest yolk weight obtained at an estimated maximal GPR inclusion level of $4.18 \%$. Yolk pigmentation also presented a quadratic response, with minimal pigmentation achieved at an estimated GPM level of 3.2\%.

The increasing density of yolk pigmentation observed in this study may be related to the presence of anthocyanins in the grape pomace flour. Anthocyanins are pigments that provide the purple color to grapes and their products (Abe, 2007). In addition of their coloring potential, these compounds present antioxidants and antibacterial properties (Ho et al., 2010). Antioxidant supplements improve the quality of foods of animal origin in terms of color, oxidative stability, and storage properties (Kara et al., 2016).

In the commercial hen egg market, richer-colored yolks are desirable, and this characteristic depends exclusively on the feed, because even though hens are not able to synthesize pigments, they are able to 
Fróes HG, Jácome IMTD, Tavares RA,

Garcia RG, Domingues CHF,

Bevilaqua TMS, Martinelli M,

Naas IA, Borille $\mathbf{R}$

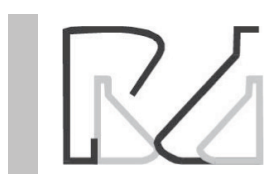

Grape (Vitis Vinifera) Pomace Flour as Pigment Agent of Quail Eggs
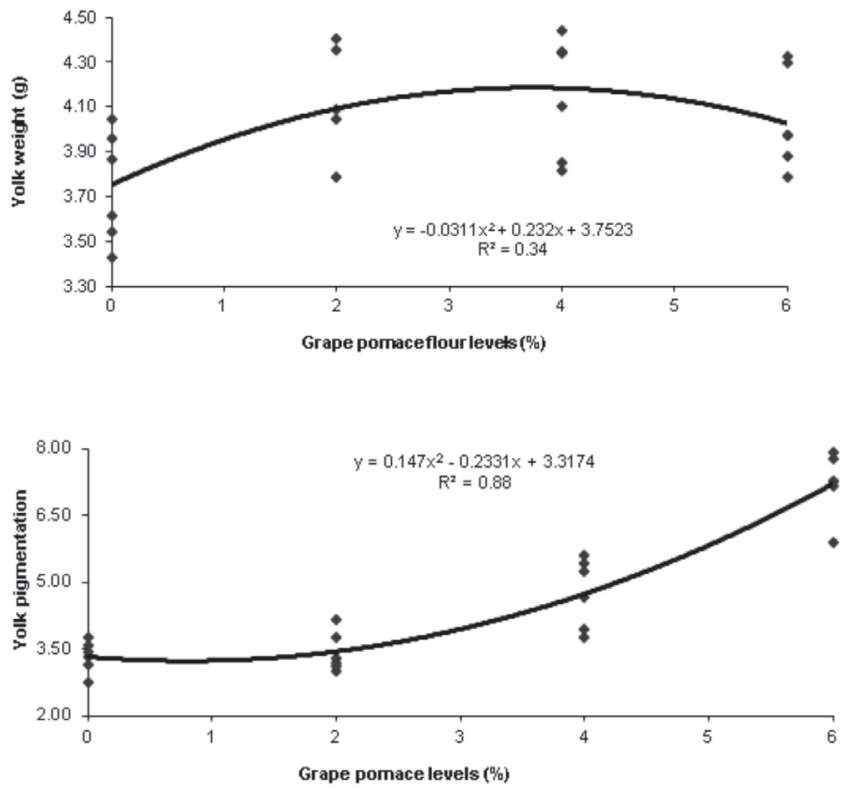

Figure 3 - Yolk weight $(\mathrm{g}$ ) and yolk pigmentation of quails fed with diets containing different levels of grape pomace flour during production.

absorb between $20 \%$ and $60 \%$ of the feed pigments (Moura et al., 2011). According to Klassing (1998), pigment deposition in specific tissues depends on its levels in the diet, tissue growth rate, and the bird's ability to digest, absorb, and metabolize it.

The impact of the inclusion of grape pomace on performance and egg quality of poultry can be influenced by several factors. Such factors include its total polyphenol content, which depends on the grape variety and the soil where they were grown, as well as the processing methods from which the pomace is derived, e.g., for the production of wine, vinegar, or grape juice (Kara et al., 2016).

\section{CONCLUSIONS}

Egg yolk pigmentation improved at a minimal inclusion level of $3.2 \%$ of grape pomace flour in the diet of quails in lay, demonstrating its efficiency of as pigmentation additive. The inclusion of grape pomace flour up to $4.18 \%$ of the diet increased yolk weight. However, the dietary inclusion of grape pomace flour compromised egg weight, albumen weight, and egg specific gravity. Further studies are required aiming at minimizing the possible adverse effects of the inclusion of grape pomace flour in quail diets.

\section{REFERENCES}

Abe LT, Mota RV, Lajolo FM, Genovese MI. Compostos fenólicos e capacidade antioxidante de uvas Vitis labrusca e Vitis vinifera L. Revista Ciência e Tecnologia de Alimentos 2007;27(2):394-400.
AOAC - Association of Official Analytical Chemists. Official methods of analysis. $18^{\text {th }}$ ed. Washington; 2007. 3000 p.

Bagchi D, Bagchi M, Stohs SJ, Das DK, Ray SD, Kuszynski CA, et al. Free radicals and grape seed proanthocyanidin extract: Importance in human health and disease prevention. Toxicology 2000;148:187-197.

Bertechin GA. Nutrição de monogástricos. Lavras: Editora UFLA; 2012. p.373.

Bozkurt M, Küçükyilmaz K, Çatli AU, Çinar $M$, Bintaş $E$, Çöven $F$ Performance, egg quality, and immune response of laying hens fed diets supplemented with mannan-oligosaccharide or an essential oil mixture under moderate and hot environmental conditions. Poultry Science 2012;91:1379-1386.

Brenes A, Viveros A, Goñi I, Centeno C, Saura-Calixto F, Arija I. Effect of grape seed extract on growth performance, protein and polyphenol digestibility, and antioxidant activity in chickens, Span. Journal of Agriculture Research 2010;8:326-333

Brenes A, Viveros A, Chamorro S, Arija I. Use of polyphenol-rich grape byproducts in monogastric nutrition. Animal Feed Science and Technology 2016;211:1-17

Chamorro S, Viveros A, Centeno C, Romero C, Arija I, Brenes A. Effects of dietary grape seed extract on growth performance, amino acid digestibility and plasma lipids and mineral content in broiler chicks. Animal 2013;7:555-561.

Gilani G, Xiao C, Cockell K. Impact of antinutritional factors in food proteins on the digestibility of protein and the bioavailability of amino acids and on protein quality. British Journal of Nutrition 2012;108:315-332.

Hernández JM, Seehawer J, Hamelin C, Bruni M, Wakeman W. Egg quality: the european consumer's perception. Basel: Roche Vitamins Europe; 2001.

Ho CT, Rafi MM, Ghai G. Substâncias bioativas: Nutracêuticas e tóxicas. In: Damodaran S, Parkin KL, Fennema OR, editors. Química de alimentos de Fennema. $4^{\text {th }}$ ed. Porto Alegre: Artmed; 2010. p.585-609.

IBGE- Instituto Brasileiro de Geografia e Estatística. Produção da pecuária municipal. Rio de Janeiro; 2015. p.48.

Ipek A, Sahan U, Yilmaz B. The effect of hatch weight on Japanese quails (coturnix coturnix japonica) growth and egg production traits. Uludağ Üniversitesi Ziraat Fakültesi Dergisi 2003;7:23-32.

Keener KM, Lacrosse JD, Curtis PA, Anderson KE, Farkas BE. The influence of rapid air cooling and carbon dioxide cooling and subsequent storage in air and carbon dioxide on shell egg quality. Poultry Science 2000:79:1067-1071.

Klassing KC. Comparative avian nutrition. New York: CAB International;1998. p.350.

Lobera A, Canellas J. Dietary fiber content and antioxidant activity of Manto Negro red grape (Vitis vinifera) pomace and stem. Food Chemistry 2007:101:659-666.

Leeson S, Summers JD. Scott's nutrition of the chicken. $4^{\text {th }}$ ed. Guelph: University Books; 2001

Manach C, Scalbert A, Morand C, Rémésy C, Jiménez L. Polyphenols: food sources and bioavailability. American Journal of Clinical Nutrition, 2004;79(5):727-747.

Mirzah N, Djulard A. Marigold flower extract as a feed additive in the poultry diet: Effects on laying quail performance and egg quality. International Journal of Poultry Science, 2017;16:11-15

Minitab. Minitab. version 16.1.0. Pennsylvania: State College; 2010 
Fróes HG, Jácome IMTD, Tavares RA,

Garcia RG, Domingues CHF,

Bevilaqua TMS, Martinelli M,

Naas IA, Borille $\mathbf{R}$

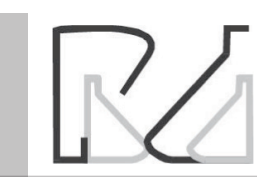

Grape (Vitis Vinifera) Pomace Flour as Pigment Agent

of Quail Eggs
Monrad JK, Howard LR, King JW, Srinivas K, Mauromoustakos A. Subcritical solvent extraction of anthocyanin from dried red grape pomace. Journal of Agricultural and Food Chemistry 2010;58:2862-2868.

Moreng RE, Avens JS. Ciência e produção de aves. São Paulo: Roca;1990. p.227-249.

Moura AMA, Takata FN, Nascimento GR, Silva AF, Melo TV Cecon PR. Pigmentantes naturais em rações à base de sorgo para codornas japonesas em postura. Revista Brasileira de Zootecnia 2011;40:24432449.

Özeku K, Wellmann KT, Ertekin B, Tarim B. Effects of dietary herbal essential oil mixture and organic acid preparation on laying traits, gastrointestinal tract characteristics, blood parameters and immune response of laying in a hot summer season. Journal of Animal and Feed Sciences 2011;20:575-586.

Ozgan A. Use of grape seed oil in functional egg production [thesis]. Adana (TUR): University of Cukurova; 2008.

Radwan LN, Hassan RA, Qota EM, Fayek HM. Effect of natural antioxidant on oxidative stability of eggs and productive and reproductive performance of laying hens. International Journal of Poultry Science 2008;7:134-150

Rossi P, Nunes JK, Rutz MA, Anciuti MA, Moraes PVD, Takahashi SE, et al. Effect of sweet green pepper on yolk color and performance of laying hens. Journal Applied Poultry Research 2015;24:10-14.
Rostagno HS, Albino LFT, Donzele JL, Gomes PC, Oliveira RF, Lopes DC. Tabelas brasileiras para aves e suínos: composição de alimentos e exigências nutricionais. 3.ed. Viçosa: Universidade Federal de Viçosa; 2011. 252p.

Roy DM, Schneeman BO. Effect of soy protein, casein and trypsin inhibitor on cholesterol, bile acids and pancreatic enzymes in mice. Journal of Nutrition 1981;111:878-885.

Salici S, Kocaoğlu-Güçlü B, Kara K. Effect of supplementation of crushed grape seed on breeding quail (Coturnix Coturnix Japonica) diet on production, hatching performance, and egg quality. Journal of Health Science Erciyes 2011;20:68-76.

Shrikhande AJ. Wine by-products with health benefits. Food Research International 2000;33:469-474

Shahidi F, Janitha PK, Wanasundara PD. Phenolic antioxidants. CRC Critical Reviews in Food Science and Nutrition, Boca Raton 1992;32(1):67-103.

Zahroojian N, Moravej H, Shivazad M. Effects of dietary marine algae (Spirulina platensis) on egg quality and production performance of laying hens. Journal of Agricultural Science and Technology 2013;15:1353-1360.

Zhao X, Yang ZB, Yang WR, Wang Y, Jiang SZ, Zhang GG. Effects of ginger root (Zingiber officinale) on laying performance and antioxidant status of laying hens and on dietary oxidation stability. Poultry Science 2011:90:1720-1727. 